\title{
Heavy Metal Acquisition from Drain Water, Sediment and Soil by two Species of Amphibious Plants
}

Sanaa A. I. Moussa

Department of Botany \& Microbiology, Faculty of Science, Cairo University, Giza, Egypt.

\begin{abstract}
TE PRESENT study was carried out in El-Khmseen canal, which receives irrigation water from a main, AL-Zomar canal, which passes, along Saft El-Laban town in Giza Governorate. El-Khamseen canal lies about $8.2 \mathrm{~km}$ southwest of Cairo University, Giza, Egypt. The canal is contaminated with the agricultural effluents, in addition to a lot of domestic pollutants and discharges resulting from the small industrial units such as paints and ceramic manufacturing. Additional sources of pollution are burning of charcoal and garbage by the farmers and the traffic emissions. The study was focused on the assessment of heavy metal content in two aquatic and one canal bank macrophytes in comparison with water, sediment and soil. Different plant parts (viz. rhizomes, living leaves, dead leaves and living roots) representing two aquatic macrophytes (Cyperus alopecuroides and Phragmitis australis) and a third canal bank species; Phragmitis australis. Sediments, soil and water, were analyzed for $\mathrm{Mn}, \mathrm{Cu}, \mathrm{Zn}$, $\mathrm{Cd}, \mathrm{Pb}$ and $\mathrm{Fe}$. Results elucidated that concentrations of $\mathrm{Mn}, \mathrm{Cu}$ and $\mathrm{Pb}$ were higher in soils than in sediments. Roots were the most efficient hyperaccumulating organs, giving higher bioconcentration factor (BCF) values. The contents of heavy metals in the studied species followed the order: $\mathrm{Fe}>\mathrm{Mn}>\mathrm{Zn}>\mathrm{Cu}>\mathrm{Pb}>\mathrm{Cd}$. The investigation elucidated that the living roots of the studied species are hyperaccumulators for $\mathrm{Fe}$, moderate accumulators for $\mathrm{Mn}$, and $\mathrm{Zn}$, poor accumulators for $\mathrm{Cu}$ and $\mathrm{Pb}$ and scarce accumulators for $\mathrm{Cd}$. The content of all metal ions in the different organs of the studied species obeyed the order: living roots $>$ dead roots $>$ dead leaves $>$ living leaves $>$ culms and rhizomes. High Translocation Factor (TF) values of the test species confirm the capability of their roots to accumulate heavy metals and their translocation to the shoots. Therefore, rhizofiltration was found to be the best mechanism to explain that Phragmites australis and Cyperus alopecuroides are promising species for phytoremediation of wastewater and soil.
\end{abstract}

Keywords: Rhizofiltration - Heavy metals - Bioconcentration Translocation Factor.

Pollution of water is a tremendous environmental problem in Egypt. Conventional physical and chemical systems require major investments in equipment and facilities and have high running costs. More economic 
alternatives of wastewater remediation are being pursued, including phytoremediation with certain aquatic and wetland plants that have phytoextraction and rhizofiltration capabilities (Wang et al., 2002). Phytoremediation, the use of vegetation for the in situ treatment of contaminated soils and sediments, is an emerging technology that promises the effective and inexpensive cleanup of hazardous waste sites. Phytoremediation typically costs only 10 to $50 \%$ as much as traditional remediation techniques such as soil excavation (Schnoor et al., 1995). The success of this green technology depends on the production of sufficient plant biomass for accumulating high concentrations of heavy metals and application of agricultural practices that allow repeated planting and harvesting of the metal-rich tissues (Paz-Alberto and Sigua, 2013). Phytoremediation of soils contaminated with heavy metals has proven to be environmentally friendly. This approach has developed quickly throughout the world, because the use of certain aquatic and wetland plants to extract pollutants in wastewater treatment is considered, by researchers, to be an effective measure for removing heavy metals (Mojiri, 2012; Paz-Alberto \& Sigua, 2013 and Sukumaran, 2013).

Heavy metals are common environmental pollutants that are produced as the result of industrial, commercial and domestic activities. Runoff from the agricultural sector frequently contains pollutants that may have an adverse effect on River Nile. Pollutants such as salts, nutrients like phosphorus and nitrogen, and pesticide residues can be found in this runoff (Ezzat et al., 2002). Discharge of untreated or partially treated industrial and domestic wastewater, leaching of pesticides and residues of fertilizers are the most important factors that affect the quality of ground and nearby surface water bodies. There has been some success in mitigating the effects of agricultural effluents as pollutants. This is a result of increased regulation concerning the use of agrochemicals. A decrease in the use of these chemicals has tended to make the wastewater from this sector considerably healthier. Heavy-metal pollution in agricultural areas owing to traffic emissions may contaminate the crops growing near the roadways (Zeng, 2008). In agricultural areas, uptake of heavy metals through the soil-crop system could play a predominant role in human exposure to these heavy metals (Liu et al., 2007). Although many metals are essential, all metals are toxic at high concentrations, because they cause oxidative stress by formation of free radicals. Another reason why metals may be toxic is that they can replace essential metals in pigments or enzymes disrupting their function (Henry, 2000).

Studies in different countries of the world show that heavy metals can be found in municipal wastewater even when major industrial sources are not part of the system (Wang et al., 2002). In Egypt, the River Nile is the primary source of fresh water, in addition to the underground water in some desert areas. The drainage canals are floristically richer than the irrigation canals (Mashaly et al., 2010). To investigate feasible approaches for reducing the eutrophication of surface waters and for the removal of heavy metals, the present investigation was conducted. Specifically, this study focuses on the ability of the different plant organs of two perennial amphibians; Cyperus alopecuroides Rottb., Descr. Egypt. J. Bot., 55, No. 1 (2015) 
(Cyperaceae) and Phragmites australis (Cav.) Trin. Ex Stued. (Graminae) to extract and accumulate $\mathrm{Mn}, \mathrm{Cu}, \mathrm{Zn}, \mathrm{Cd}, \mathrm{Pb}$ and $\mathrm{Fe}$ from polluted water, soils and sediments; as a perspective for the potential use of such species in the phytoremediation systems.

The study area

\section{Material and Methods}

Saft El-Laban is a small town located at the south western part of Giza Governorate, Egypt (Lat. $+31^{\circ} 10^{\prime} 11.2326^{\prime \prime}$ and Alt. $\left.+30^{\circ} 1^{\prime} 46.149^{\prime \prime}\right)$. It lies at a distance of about $8.2 \mathrm{~km}$ of Cairo University. The majority of this town consists of farmlands cultivated with many economic crops. Until the year 2000, the fields were irrigated with the Nile water diverted to the area through a series of irrigation canals. Since 2001, the farmers are using the ground water in irrigation to compensate the limited water of the irrigation canals diverted to the fields. This irrigation system led to soil salinity and crumbling. Domestic, agricultural drains and seepage water from landfills have caused serious pollution problems. Water inflow to the study area was undertaken in EL-Khamseen canal; a branch of Al-Zomar larger Nile canal providing Giza Governorate. Not only is the canal subjected to the agricultural effluents but also too many domestic pollutants and discharges resulting from the small industrial units such as paints and ceramic manufacturing. These units dump their untreated effluents in the surface drains, which spread over the nearby agricultural fields. Additional sources of pollution include burning of charcoal and garbage by the farmers, as well as the traffic emissions. In this canal, raw sewage is often used with underground water for irrigation of croplands planted with vegetables. In addition, the distant cultivated lands around the canal are also re-irrigated with the agricultural effluents mixed with the ground water. The two studied species; Cyperus alopecuroides and Phragmites australis are occupying the free water surface of El-Khamseen canal as well as most aquatic systems in Egypt. The study was carried out during the winter of 2014 .

The studied species

Cyperus alopecuroides Rottb., Descr.; a perennial species which grows in canal banks, drains, ditches, pools, lakes, rice fields and marshy ground (Bolous, 2005). In some regions of the Nile Delta, the border between the fields if unclear is often cultivated with the species. In Faiyum Governorate, Cyperus alopecuroides is cultivated in limited areas for mat and chair-making (Bolous and El-Hadidi, 1989).

Phragmites australis (Cav.) Trin. Ex Stued. ; the common reed is a perennial grass, common along the water coarses, in areas of cultivation and sandy plains with seasonally high water table, and in temperate regions of both hemispheres of the world (Bolous, 2005). Our field observation indicated that the individuals of Phragmites australis inhabit two locations; the canal bank and the water body where they are fixed to the bottom of the canal by their rhizomes and roots. 
Sampling and analyses of water, sediments, soil and plants.

Sampling took place in February 2014. Water samples were collected from the supernatant $25 \mathrm{~cm}$ upper water zone of the canal in plastic bottles previously soaked in $10 \%$ nitric acid for $48 \mathrm{hr}$ and thoroughly rinsed with deionized-distilled water. Soil samples were collected from the root zone of the soil supporting Phragmites australis at the canal bank site while sediments were collected from the bottom of the canal where $P$. australis and $C$. alopecuroides were present. At least 10 plants of each species were collected into clean plastic bags, soaked in dilute nitric acid and thoroughly rinsed with deionized-distilled water. In the laboratory, the plants were carefully washed with distilled water and separated into different parts; rhizomes, living leaves, dead leaves and living roots, then dried in a hot air oven for $48 \mathrm{hr}$ at $65^{\circ} \mathrm{C}$. For attention, neither aquatic nor canal bank Phragmites australis had dead roots. Plant samples were ground to fine powder using a silica pistil and mortar. Samples were dried at $105^{\circ} \mathrm{C}$ for $12 \mathrm{hr}$, burned in a muffle furnace at $550^{\circ} \mathrm{C}$ for $16 \mathrm{hr}$, digested in concentrated $\mathrm{HCl}$, and diluted with de-ionized water to a known volume (Hseu, 2004). Analytical blanks were run in the same way as the samples, and concentrations were determined using standard solutions prepared in the same acid matrix. The reagents used were of analytical grade (Merck). Standards for instrument calibration were prepared on the basis of mono-element certified reference solution inductively coupled plasma standard (Merck). Standard reference material (National Institute of Standards and Technology [NIST], (USA) was used to validate analysis.

The flame atomic absorption spectrophotometer's configuration and quality control procedures were maximized and adjusted before use and the detection limits were beyond the concentration of the studied heavy metal in tissue samples. The concentrations of $\mathrm{Mn}, \mathrm{Cu}, \mathrm{Zn}, \mathrm{Cd}, \mathrm{Pb}$ and $\mathrm{Fe}$ were analyzed by flame atomic absorption spectrophotometer (Thermo Scientific ICE 3300, UK) equipped with double beam and deuterium background corrector according to APHA (2005). Concentrations were calculated as $\mu \mathrm{g} \mathrm{g}^{-1}$ dry weight.

\section{Bioconcentration Factor and Translocation Capability}

The Bioconcentration factor $(\mathrm{BCF})$ : It is a dimensionless factor also called bioaccumulation factor or enrichment coefficient. It was calculated as the ratio of a given element concentration in the plant tissues at harvest to the concentration of the element in the external environment according to Eq.1 (Sutapa and Bhattacharyya, 2008).

$$
\mathrm{BCF}=\mathrm{P} / \mathrm{E}
$$

Where $\mathrm{P}$ represents the element concentration in plant tissues $\left(\mu \mathrm{g} \mathrm{g}^{-1}\right.$ dry wt) and $\mathrm{E}$ represents the element concentration in sediment $\left(\mu \mathrm{g} \mathrm{g}^{-1}\right.$ dry $\left.\mathrm{wt}\right)$. A larger ratio implies better phytoaccumulation capability. 
Translocation factor (TF)

It was calculated by dividing the concentration of a trace element accumulated in the root tissues by that accumulated in shoot tissues (Sutapa and Bhattacharyya, 2008). TF is given by Eq. 2.

$$
\mathrm{TF}=\left(\mathrm{A}_{\mathrm{r}} / \mathrm{A}_{\mathrm{s}}\right)
$$

Where $A_{r}$ represents the amount of trace element accumulated in the roots $(\mu \mathrm{g}$ $\mathrm{g}^{-1}$ dry wt) and $A_{\mathrm{s}}$ represents the amount of trace element accumulated in the shoots $\left(\mu \mathrm{g} \mathrm{g}^{-1}\right.$ dry wt). TF is also called translocation capability factor where a larger ratio implies higher translocation capability.

\section{Statistical analysis}

All analyses results (average of three replicates) were subjected to ANOVA to determine the mean, standard deviation, and the significance using the SPSS version 22 .

\section{Results and Discussion}

The drainage of irrigation water from farmlands poses a serious threat for environmental water pollution. It usually contains high levels of hazardous materials and the removal of such substances is a hard task and not feasible with the routine treatments. For more than one decade, the cultivation around the studied El-Khamseen canal of the study area depends on the ground water due to the shortage in Nile water supply driven to the irrigation canals. The drain water of agricultural soil around the canal was spilled in it and pumped to irrigate the adjacent fields. This process carries all the remnants of pesticides, herbicides and chemical fertilizers to the cultivated croplands. In addition, local residents released many wastes and some local industrial activities (such as industries of paints and ceramics in addition to the empty cans, etc.) are disposed into the canal. All these wastes are possibly responsible for heavy metal pollution of water. The application of drain water in irrigation process possibly creates pollution of soil, which affects the food chains of the ecosystem (Sukumaran, 2013). Due to the increase in population and shortage in fresh water, recycling of sewage water is essential. High levels of total dissolved salts [TDS] (ranged from $550 \& 1103 \mathrm{mg} \mathrm{l}^{-1}$ ) in current and stagnant water, respectively were quantified in the drain water of the studied area. Although the Environmental Protection Agency (EPA) suggests a maximum level of $250 \mathrm{mg} \mathrm{l}^{-1}$ of TDS in fresh water to minimize harm to humans and aquatic ecosystem (US EPA, 2001), higher values within these systems are probable due to human activities. The soil moisture content in the root zone at the canal bank of Phragmites australis plants averaged for $34 \%$ (unpublished data of field studies).

\section{1-Concetration of heavy metals in the different organs of the studied species}

Generally, highest contents of all tested metals were significantly recorded in the living roots and dead leaves of the studied species (Table 1). On the contrary, least metal contents were monitored for their rhizomes. The content of the 
different assessed metals varied in the different plant parts (rhizome, living leaves, dead leaves and living roots) of the studied species. As regards the $\mathrm{Mn}$ content, highly significant contents of $279.31,271.15$ and $327.48 \mu \mathrm{g} \mathrm{g}^{-1}$ dry wt, respectively were monitored for the living roots of the aquatic Cyperus alopecuroides, aquatic and canal bank Phragmites australis. Aquatic Cyperus alopecuroides attained the highest total mean values of $\mathrm{Cu}, \mathrm{Zn}, \mathrm{Cd}$ and $\mathrm{Pb}$ when compared to the other two species. The data indicated that the $\mathrm{Mn}$ bioaccumulation by the species was following the order: living roots > dead leaves $>$ living leaves $>$ rhizomes. This disagrees with Hegazy et al. (2011). The authors found that the bioaccumulation of heavy metals by Typha domingensis takes the order: yellow parts > roots and rhizomes $>$ leaf bases $>$ green parts. The content of $\mathrm{Cu}$ varied between the different plant parts of Phragmites inhabiting the canal bank habitat. The living roots of the later species caught high value of $48.16 \pm 14.43 \mu \mathrm{g} g-1$ dry wt. The roots of the aquatic Cyperus plants $(44.84 \pm 4.05$ $\mu \mathrm{g}$ g-1 dry wt) followed this. Liao and Chang (2004) reported that water hyacinth is a promising candidate for phyoremediation of heavy metals; including $\mathrm{Cu}$.

They added that the concentration of $\mathrm{Cu}$ and other heavy metals in hyacinth roots was 3-15 times higher than in shoots. Generally, the contents of $\mathrm{Cu}$ in the dead leaves of aquatic Cyperus (12.69) and the canal bank Phragmites plants (9.77) were higher than those in their living green leaves (6.67 and $0.67 \mu \mathrm{g} g-1$ dry wt, respectively). The contents of $\mathrm{Cu}$ were lower in the rhizomes than in the living roots of the studied species. Generally, the content of copper was arranged in the order: living roots > dead leaves > living leaves > rhizomes. According to Anita et al. (2010) .The concentration of copper in plants exceeds the permissible limits (Table 6). This trend represents a great threat for the aquatic biota and - in turn - for man. Zinc is one of the most common essential trace elements in the world as it naturally occurs in air, soil, water and in most foods. It is required in small but critical amounts by both plants and animals (including humans). Plants absorb zinc primarily as a divalent cation, which acts either as a metal component of enzymes or as a functional, structural or regulatory cofactor of a large number of enzymes (Dabkowska - Naskret, 2003). It enters the environment from a variety of human activities such as mining, steel production, cool burning and burning of wastes (Kabata-Pendias and Pendias, 1999). For instance, zinc and cadmium can lead to acute gastrointestinal and respiratory damages and acute heart, brain and kidney damages (Lone et al., 2008). Zinc is up taken and accumulated by the highly bioaccumulating organs, especially the living roots $\left(153.43,59.22\right.$ and $115.34 \mu \mathrm{g} \mathrm{g}^{-1}$ dry wt) of the tested species - as arranged in the table - exceeding the permissible limits. These levels may be attributed to the activities of the local residents and reflects the high metal accumulating capacity of the species.

The dead leaves of canal bank Phragmites australis as well as and rhizomes of the aquatic Cyperus alopecuroides recorded high $\mathrm{Zn}$ contents (30.58 and 71.33 $\mu \mathrm{gg}^{-1}$ dry wt). Phytotoxic limits of $\mathrm{Zn}$ in plants are in the range $200-500 \mathrm{mg} \mathrm{kg}^{-1}$ (Levy et al., 1999). These levels may be attributed to the activities of the local 
residents and reflects the high metal accumulating capacity of the species. This is also due to zinc high mobility and bioavailability of some of its soluble compounds as it is found in soil in complexes, like $\mathrm{ZnOH}^{+}, \mathrm{ZnHCO}_{3}{ }^{+}, \mathrm{Zn}(\mathrm{OH})_{3}{ }^{-}$ and $\mathrm{ZnO}_{2}^{-}$(Kabata-Pendias \& Pendias, 1999).

The content of zinc in the studied species was arranged according to the order: living roots > dead leaves > living leaves > rhizomes. Cadmium levels in the environment vary widely. In soils, it is derived from both natural (including underlying bedrock or transported material) and anthropogenic sources (by aerial deposition, sewage sludge, manure and phosphate fertilizer application) (Jensen and Rasmunssen, 1992). Only the living roots and the rhizomes of the aquatic Cyperus alopecuroides ( 0.39 and $0.27 \mu \mathrm{g} \mathrm{g}^{-1} \mathrm{dry} \mathrm{wt}$ ) as well as the living roots of the canal bank Phragmites australis $\left(0.51 \mathrm{\mu g} \mathrm{g}^{-1}\right.$ dry wt) acquired feasible values of cadmium. It is to be mentioned that the non-essential heavy metals compete for the same transmembrane carriers used by the essential heavy metals. For example, kinetic data demonstrate that essential copper, zinc, non-essential cadmium and nickel compete for the same transmembrane carrier (Crowley et al., 1991).

The biomass of the aboveground parts of a certain species reflects its capability for metal ion concentration. Lead is one of the most difficult nonessential contaminants to be removed from the soil and one of the most dangerous. According to Lasat (2000), the presence of lead in the environment can have devastating effects on plant growth and can result in serious side effects including; seizures and mental retardation if ingested by humans or animals. It adversely affects plant seed germination, nutrient assimilation, photosynthesis and growth (Changcun et al., 2010). Much of global lead contamination has occurred because of mining and iron smelting activities (Cortez, 2005), burning of fossils, fuels, dumping of municipal sewage sludge, and the manufacture of pesticides and fertilizers (Kabata-Pendias and Pendias, 1999). As regards the low content of lead in the studied species, the concentrations were above the permissible levels. In non-polluted sites in Poland, the studies indicated that the mean values of lead concentrations in soil ranged from 25-40 ppm (KabataPendias and Pendias, 1999).

The low lead contents in the different shoot organs (such as rhizomes, living and dead leaves) in the case of aquatic and canal bank Phragmites australis evinces the idea of immobilization of lead in soil because lead is known to be "molecularly sticky" since it readily forms a precipitate within the soil matrix (Paz-Alberto and Sigua, 2013). Authors added that lead has low aqueous solubility and in many cases, it is readily bioavailable. In most soils capable of supporting plant growth, the soluble $\mathrm{Pb}^{+2}$ levels are relatively low and will not promote substantial uptake by the plant even if it has the genetic capacity to accumulate the metal. Many plants retain $\mathrm{Pb}^{+2}$ in their roots via absorption and precipitation with only minimal transport to the aboveground harvestable portions. Therefore, it is important to find ways to enhance the bioavailability of 
lead or to find specific plants that can better translocate the $\mathrm{Pb}^{+2}$ into harvestable portions (Kumar et al., 1995). The content of lead in the living roots of aquatic and canal bank Phragmites (5.77 and $9.65 \mu \mathrm{g} \mathrm{g}^{-1}$ dry wt, respectively) exceeded significantly that allocated by the living roots of $C$. alopecuroides $\left(1.65 \mu \mathrm{g} \mathrm{g}^{-1}\right.$ dry wt). The results of the present study coincide with Wang et al. (2002) who proved that the highest lead concentration $\left(512.4 \mathrm{mg} \mathrm{kg}^{-1}\right)$ was achieved by the roots of Lepironia articulate. The phytotoxic limits of $\mathrm{Pb}$ in plants are in the range $30-300 \mathrm{mg} \mathrm{kg}^{-1}$ (Levy et al., 1999). It is to be mentioned that the sequence of the plant organs in relation to their lead uptake was altered.

In the case of aquatic and canal bank Phragmites australis, it followed the order: living roots $>$ dead leaves $>$ living leaves $>$ rhizomes. As regards the aquatic Cyperus alopecuroides, it followed the order: dead leaves $>$ living leaves $>$ living roots $>$ rhizomes. Analysis of the plants suggests that the concentration of $\mathrm{Pb}$ in morning glory (Ipomea violacea L.) and Ottelia allismoides L. was about $210 \%$ more than the concentration of $\mathrm{Pb}$ in water (Xia \& Ma, 2005). As a general trend for all heavy metal ions, the preponderance of their high content was monitored in the living roots. Iron contributed the greatest share between the other heavy metal ions in the studied species. Enormous and highly significant values of iron (10091.1, 4303.9 and $12017.6 \mu \mathrm{g} \mathrm{g}^{-1}$ dry wt) were recorded for the living roots of aquatic Cyperus alopecuroides, aquatic and canal bank Phragmites australis, respectively.

The lowest contents (537.97, 363.15 and $222.4 \mu \mathrm{g} \mathrm{g}^{-1}$ dry wt) were recorded in their rhizomes. Iron contents in the organs of the studied species - as a general - were in the order: living roots $>$ dead leaves $>$ living leaves $>$ rhizomes. The studied species are considered iron hyperaccumulators, as their tissues contained high values (1000 $\mathrm{g} \mathrm{g} \mathrm{g}^{-1}$ of iron. dry wt) (Baker and Brooks, 1989).

2- Concentration of heavy metals in soil and water supporting the roots of the studied species

The concentration of manganese in sediments supporting the studied species varied from 172.36- $\mu \mathrm{g} \mathrm{g}^{-1}$ dry wt for aquatic Phragmites to $169.85-\mu \mathrm{g} \mathrm{g}^{-1}$ dry wt for Cyperus and reached $204.5-\mu \mathrm{g} \mathrm{g}^{-1}$ dry wt in the soil supporting Phragmites australis plants of the canal bank (Table 2). The concentration of manganese in drain water of both aquatic Cyperus alopecuroides and Phragmites australis are 0.14 and $0.7 \mu \mathrm{g} \mathrm{l}^{-1}$, respectively (Tables 3) and amounted $0.191 \mu \mathrm{g} \mathrm{l}^{-1}$ for ground water (Fig.1).

According to Anita et al. (2010), the manganese concentration in ElKhamseen canal drain water just beneath Phragmites australis exceeds the permissible limits for drinking water and this represents a risk for plants, animals and even human beings. Examination of data reveals a high statistical significant for $\mathrm{Mn}$ in the drain water supporting Phragmites australis. The differences between the contents of $\mathrm{Cu}, \mathrm{Zn}$ and $\mathrm{Pb}$ in soils supporting the studied species were significant. The concentration of copper in drain water was low and is considered below the permissible level of toxicity while the concentrations in soils recorded relatively higher values for such habitats.

Egypt. J. Bot., 55, No. 1 (2015) 


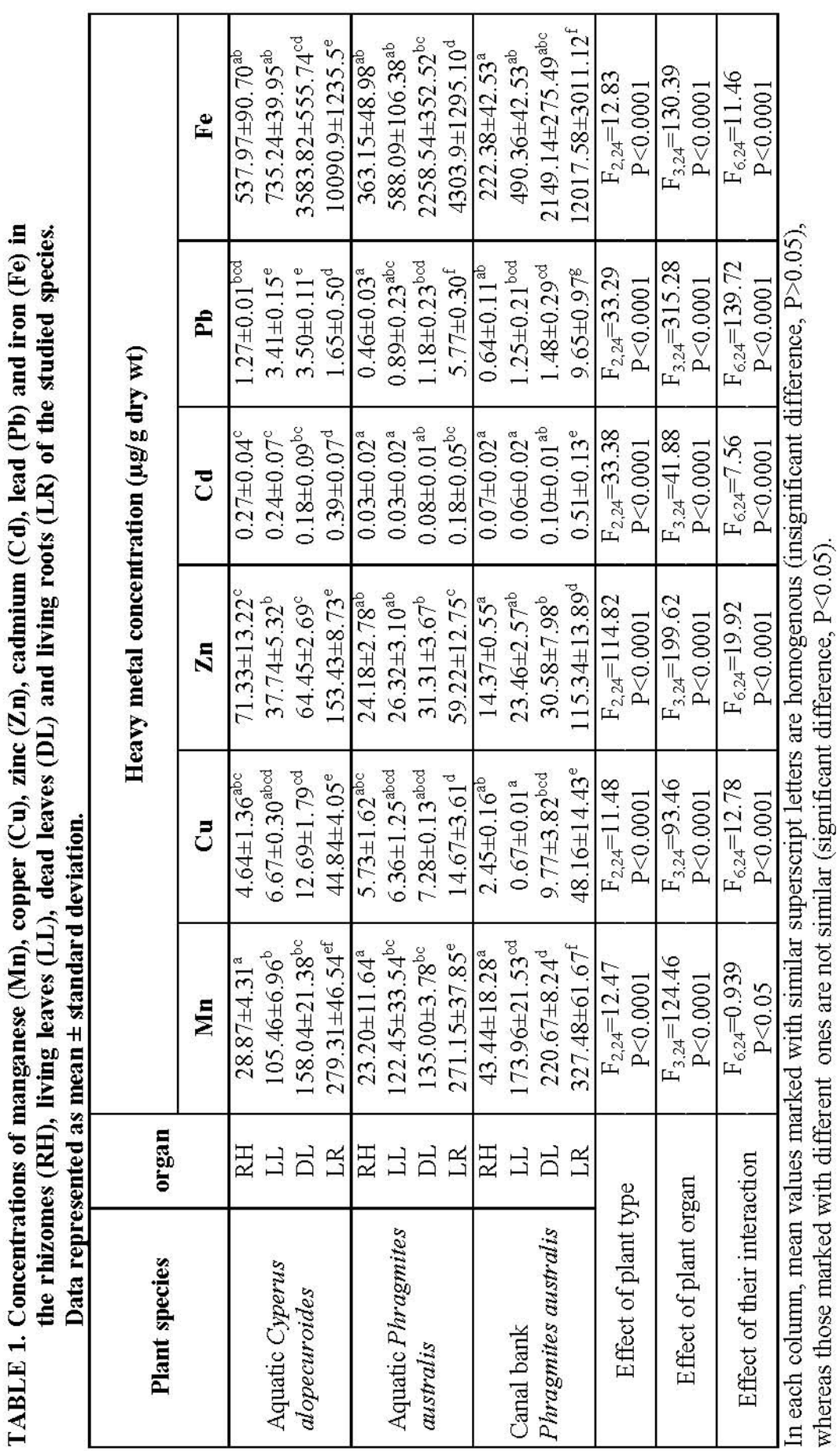

Egypt. J. Bot., 55, No. 1 (2015) 

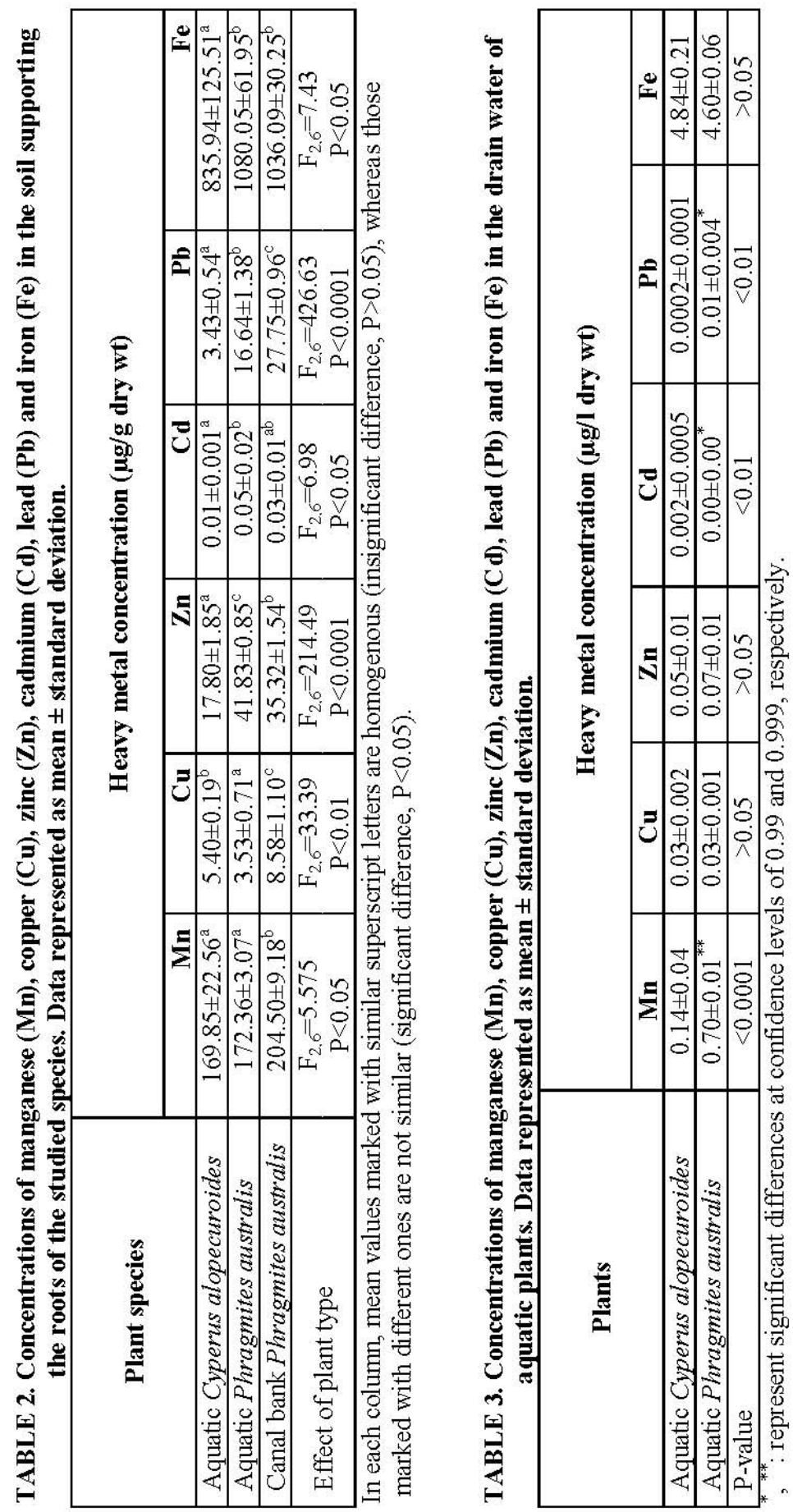

Egypt. J. Bot., 55, No. 1 (2015) 


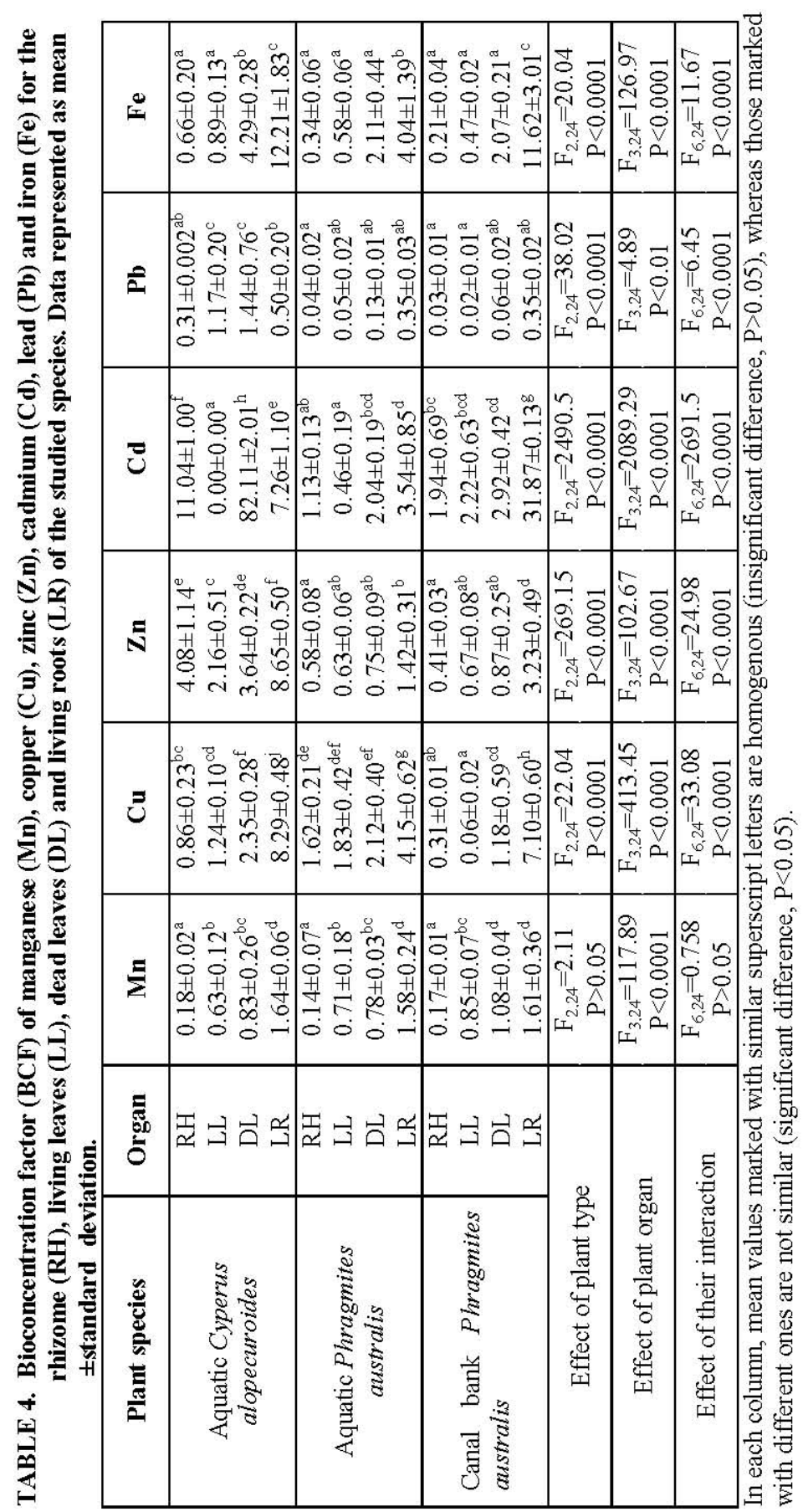

Egypt. J. Bot., 55, No. 1 (2015) 


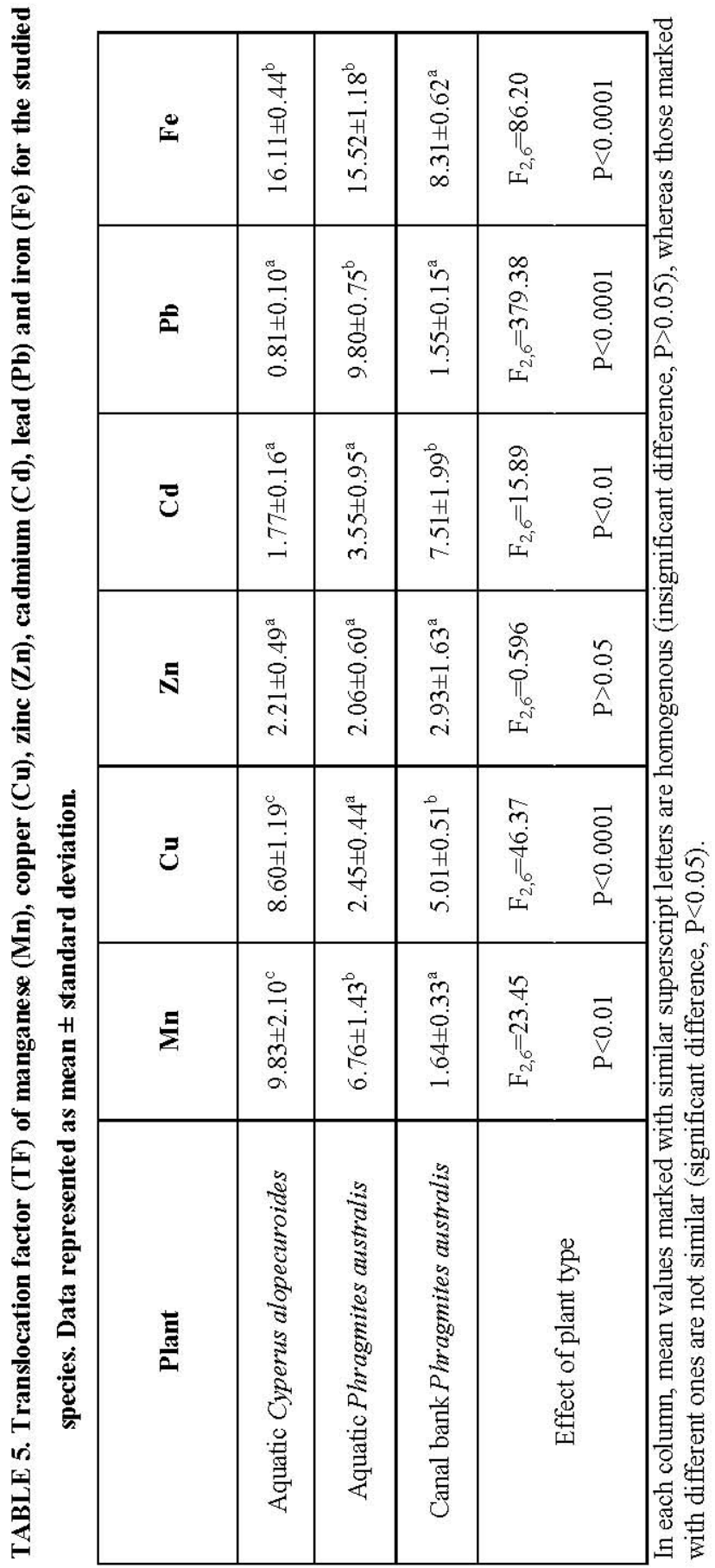

Egypt. J. Bot., 55, No. 1 (2015) 
It is to be noted that the concentration of zinc in drain water $(0.05$ and $0.07 \mu \mathrm{g}$ $1^{-1}$ ) is much more limited if compared with the permissible doses (Table 3 ). In addition, the contamination of the soil with zinc is moderately low (not more than $41.83 \mu \mathrm{g} \mathrm{g}^{-1}$ dry wt) when compared with the values estimated by Anita et al. (2010). Soil organic matter, especially in sediments, is an important constituent, which forms complexes with zinc. In turn, the deficiency of zinc in the organic soils is mainly due to this reaction (Dabkowska - Naskret, 2003). Cadmium, as a common heavy metal is toxic at both low and high concentrations and was detected in wastewater from a variety of industries (Singh et al., 2011). Neither drain water nor soil (or sediment) was contaminated with cadmium (Table 2).

Examination of Table 3 reveals that the low lead concentration in drain water was a distinctive feature and such trace values were beyond the permissible limits (Anita et al., 2010). The concentration of lead - as a heavy metal ion - in soils and sediment (Table 2) was also limited and deeply below the permissible values. The concentrations of iron in plant organs, soil and drain water were extremely high and reached the poisonous levels (Tables 1, 2 and 3). Permissible limits of iron in drinking water ranges from 0.1 to $0.3 \mu \mathrm{g} \mathrm{l}^{-1}$ (Table 6). In drain water of aquatic Cyperus alopecuroides and Phragmites australis, the iron concentrations were nearly unified, amounting 4.84 and $4.60 \mu \mathrm{g} \mathrm{l}^{-1}$, respectively. The content of iron in the ground water $\left(4.437 \mathrm{~g} \mathrm{l}^{-1}\right)$ (Fig. 1) denotes its toxicity as it exceeded the permissible dose ( 0.1 or 0.3$)$ according to ISI and FAO, respectively (Anita et al., 2010).



Fig. 1. Concentration of heavy metals in the ground water.

The source of water iron may be due to the corrosion of the irrigation pipes as well as the cans of paints and house wastes disposed in the drain canal. Huge concentrations of $1080.051,1036.09$ and $839.9 \mu \mathrm{g} \mathrm{g}^{-1}$ dry wt were estimated in sediment and soil supporting the aquatic and the canal bank Phragmites australis

Egypt. J. Bot., 55, No. 1 (2015) 
and in the sediments of the aquatic Cyperus alopecuroides, respectively. Although the sediments and soils act as sinks for many contaminants, their elevated concentrations may have implications to the integrity of ecological systems (Mercedes et al., 1998).

3- The bioconcentration value of the different organs in the studied species

The bioconcentration factor $(\mathrm{BCF})$ is a useful parameter to evaluate the potential of the plants in accumulating metals. Both BCF and TF (translocation factor) are considered when investigating whether a plant is a hyperaccumulator of a metal (Gonzaga et al., 2006). Data ensured that the living roots of the studied species significantly attained the highest BCF values for all estimated heavy metals when compared with the other plant organs (Table 4). Zinc is up taken and accumulated by the highly bioaccumulating organs, especially the living roots $(8.65,1.42$ and 3.23$)$ of the tested species - as arranged in the table These levels may be attributed to the activities of the local residents and reflects the high metal accumulating capacity of the species. This is also due to zinc high mobility and bioavailability of some of its soluble compounds as it is found in soil in complexes, like $\mathrm{ZnOH}^{+}, \mathrm{ZnHCO}_{3}{ }^{+}, \mathrm{Zn}(\mathrm{OH})_{3}{ }^{-}$and $\mathrm{ZnO}_{2}{ }^{-}$(Kabata-Pendias \& Pendias, 1999).

\section{4- The translocation factor $(T F)$ in the studied species}

In order to study the mobility of metals inside the studied species, TF values (Table 5) were calculated. TFs are used to determine the effectiveness of a plant in the translocation of metals from the roots to the shoots ( $\mathrm{Tu}$ and $\mathrm{Ma}, 2002$ ). Excluding lead in aquatic Cyperus alopecuroides, all the studied species had high (TFs) values for all metals. C. alopecuroides is a low lead trans locators, had a TF value (0.81) less than unity. Higher values of Mn translocation factor $(9.384$ and 6.76) were recorded for the aquatic Cyperus alopecuroides and Phragmites australis, respectively. Data confirmed the significance of $C$. alopecuroides as a high trans locating species for heavy metals which were arranged in the order: $\mathrm{Fe}$ $(16.11)>\mathrm{Mn}(9.83)>\mathrm{Cu}(8.60)>\mathrm{Zn}(2.21)>\mathrm{Cd}$ (1.77). In other words, TF recorded a maximum value of 16.11 for $\mathrm{Fe}$ and a minimum value of 0.81 for $\mathrm{Pb}$ in the aquatic Cyperus alopecuroides plants. The roots of the studied species were evenly trans locating organs for zinc. They achieved the TF values of 2.21, 2.06 and 2.93 , respectively.

Immobilization of inorganic contaminants can be used as a remedial method for heavy metal contaminated soils (Mench et al., 1994). This can be achieved by complexing the contaminants, or through increasing the soil $\mathrm{pH}$ by liming (Alloway and Jackson, 1991). Increased $\mathrm{pH}$ decreases the solubility of heavy metals like Cd, $\mathrm{Cu}$ and $\mathrm{Zn}$ in soil. It seemed to be a general trend for the studied species that their living roots are sufficiently hyperaccumulators for heavy metals. It is believed that these hyperaccumulators initially develop the ability to hyperaccumulate nonessential metallic compounds as a means of protecting themselves from herbivorous predators that would experience serious toxic side effects from ingestion of the hyperaccumulator's foliage (Pollard and Baker, 1997).

Egypt. J. Bot., 55, No. 1 (2015) 
When metals are concentrated in the roots, the entire plant needs to be removed. Yet the necessity of full plant removal not only increases the costs of phytoremediation, due to the need for additional labor, but also increases the time it takes for the new plants to establish themselves in the environment and begin accumulation of metals (Paz-Alberto and Sigua, 2013). It seemed that the application of using the present studied species is of the type: rhizofiltration, which is concerned with the heavy metal removal, mainly of ground and surface water rather than the remediation of polluted soils by accumulation into plant biomass (Lone, et al., 2008).

Hegazy et al. (2011) mentioned that rhizofiltration is the best mechanism to explain Typha domingensis phytoremediation. The present investigation elucidated that the living roots of the studied species (Table 1) are hyperaccumulators for $\mathrm{Fe}$, moderate accumulators for $\mathrm{Mn}$ and $\mathrm{Zn}$, poor accumulators for $\mathrm{Cu}$ and $\mathrm{Pb}$ and scarce accumulators for $\mathrm{Cd}$. Zayed et al. (1998) investigated the potential of duckweed for the removal of $\mathrm{Cd}, \mathrm{Cr}, \mathrm{Cu}, \mathrm{Ni}, \mathrm{Pb}$ and Se from nutrient - added solution. Their results indicated that duckweed is a good accumulator for $\mathrm{Cd}$ and $\mathrm{Cu}$ and poor accumulator for $\mathrm{Pb}$. Absorbed metal ions by the roots of the test species were trans located to the shoot system that should be periodically gathered. If the plants were left to die in situ, the contaminants will return to the soil or water. Therefore, for complete removal of contaminants from an area, the plants must be cut and disposed elsewhere in a non-polluting area (Paz-Alberto and Sigua, 2013).

El-Kady (2002) evinces that the nutritive values of the living parts of Phragmites australis are high and being evaluated as an excellent forage species. Shaltout et al. (2009) estimated $\mathrm{Mn}, \mathrm{Cu}$ and $\mathrm{Pb}$ in three dominant hydrophytes in the Nile Delta of Egypt. They found that Ceratophyllum demersum had the highest ability to accumulate heavy metal ions than other hydrophytes and considered the dead parts of those hydrophytes as poor accumulators. Shaltout et al. (2013) stated that the accumulating capacity of a certain species shows a great seasonal variation, owing to its seasonal phenological behavior. The living and dead parts of Panicum repens accumulated more concentrations of $\mathrm{Cu}, \mathrm{Mn}$, $\mathrm{Zn}$ and $\mathrm{Pb}$ than those of Cynodon dactylon during winter; while the dead parts of both species accumulated the highest concentrations during autumn. In a trial to assess the potential of Phragmites australis to accumulate elements and to use as a forage plant, Al-Sodany et al. (2013) showed that the accumulation of $\mathrm{Mn}, \mathrm{Pb}$, $\mathrm{Cu}, \mathrm{Cd}, \mathrm{Zn}$ and $\mathrm{Fe}$ in the plant's different organs followed the order: rhizome $>$ stem $>$ leaves. They ensured that $P$. australis is a good accumulator and a bioindicator of heavy metals in the polluted water bodies. They stated that the underground rhizomes had the ability to be used as a phytoremediator. On the other hand, the accumulation rates of some wetland spp. followed the order: stem $>$ roots $>$ leaves and obeyed the order: $\mathrm{Pb}>\mathrm{Cu}>\mathrm{Fe}>\mathrm{Mn}>\mathrm{Cd}$; especially for Mentha longifolia (Farrag et al., 2013). Finally, we might conclude that Phragmites australis and Cyperus alopecuroides are good candidates and should be added to the list of more than 400 plant species, which have been identified to have potential for soil and water remediation (Lone, et al., 2008). It is to be noted 
that the accumulation of the six estimated heavy metals followed a unified descending order: $\mathrm{Fe}>\mathrm{Mn}>\mathrm{Zn}>\mathrm{Cu}>\mathrm{Pb}>\mathrm{Cd}$ for the studied species.

Studied species are hyperaccumulators for all the assessed heavy metals (Table 3). The (BCFs) of $\mathrm{Cu}$ attained the highest values of 8.29, 4.15 and 7.10 in the living roots of aquatic Cyperus alopecuroides, aquatic and canal bank Phragmites australis, respectively. High bioconcentration values of $\mathrm{Cu}(1.62$, $1.83,2.12$ and 4.15) were observed in the rhizomes, living leaves, dead leaves and living roots of the aquatic Phragmites australis. It is to be mentioned that all the organs of the aquatic $C$. alopecuroides are zinc hyperaccumulators. This evinces the zinc high mobility and bioavailability of some of its soluble compounds in soil. In spite of the limited cadmium accumulation in the test species, nearly, all the organs of both aquatic Cyperus alopecuroides and canal bank Phragmites australis possessed high BCF values. Hence, both species are cadmium hyperaccumulators. Higher values $(82.11,11.04$ and 7.26, respectively) were amounted for the dead leaves, rhizomes and living roots of C.alopecuroides. Only lead (BCFs) values were lower than unity in the living roots of the studied species. This was compensated by its hyperaccumulation in dead leaves (1.44), especially in the aquatic Cyperus alopecuroides plants.

Permissible dose of heavy metals in soil, drinking water and plants:

The permissible doses of heavy metals are shown in Table 6 according to the Indian Standard Institution (ISI), World Health Organization (WHO/FAO), European Union Standard (EU) and Interim National Water Quality Standard for Malaysia (INWQS) after Anita et al., 2010).

TABLE 6. Guideline for safe limits of heavy metals.

\begin{tabular}{|c|c|c|c|c|c|c|c|}
\hline Sample & Standards & $\mathbf{C d}$ & $\mathbf{C u}$ & $\mathbf{P b}$ & $\mathbf{Z n}$ & Mn & $\mathbf{F e}$ \\
\hline \multirow[t]{3}{*}{ Soil $\left(\mu \mathrm{g} \mathrm{g}^{-1}\right)$} & $\begin{array}{l}\text { Indian Standard } \\
\text { (Awashthi 2000) }\end{array}$ & $3-6$ & $135-270$ & $\begin{array}{l}250- \\
500\end{array}$ & $\begin{array}{l}300- \\
600\end{array}$ & - & - \\
\hline & WHO/FAO (2007) & - & - & - & - & - & - \\
\hline & $\begin{array}{l}\text { European Union Standard } \\
\text { (EU 2002) }\end{array}$ & 3.0 & 140 & 300 & 300 & - & - \\
\hline \multirow[t]{4}{*}{ Water $\left(\mu \mathrm{g} \mathrm{g}^{-1}\right)$} & $\begin{array}{l}\text { Indian Standard } \\
\text { (Awashthi 2000) }\end{array}$ & 0.01 & 0.05 & 0.10 & 5.0 & 0.10 & 0.30 \\
\hline & FAO (1985) & 0.01 & 0.20 & 5.0 & 2.0 & 0.20 & 0.10 \\
\hline & $\begin{array}{l}\text { European Union Standard } \\
\text { (EU 2002) }\end{array}$ & - & - & - & - & - & \\
\hline & $\begin{array}{l}\text { Class 1V, Interim } \\
\text { National Water Quality } \\
\text { Standard for Malaysia } \\
\text { (INWQS 1985) }\end{array}$ & 0.01 & 0.20 & 5.0 & 2.0 & 0.20 & \\
\hline \multirow[t]{3}{*}{ Plant $\left(\mu \mathrm{g} \mathrm{g}^{-1}\right)$} & $\begin{array}{l}\text { Indian Standard } \\
\text { (Awashthi 2000) }\end{array}$ & 1.5 & 30.0 & 2.5 & 50.0 & - & \\
\hline & WHO/FAO (2007) & 0.20 & 40.0 & 5.0 & 60.0 & - & \\
\hline & $\begin{array}{l}\text { European Union Standard } \\
\text { (EU 2006) }\end{array}$ & 0.20 & - & 0.30 & - & - & \\
\hline
\end{tabular}

Source: Anita et al., 2010

Egypt. J. Bot., 55, No. 1 (2015) 


\section{Conclusions}

Phytoremediation or the green technology is a preferential cheap method for the elimination of contaminants $(\mathrm{Mn}, \mathrm{Cu}, \mathrm{Zn}, \mathrm{Cd}, \mathrm{Pb}$ and $\mathrm{Fe}$ ) from drain water, sediments and soils. Results showed that concentrations of $\mathrm{Mn}, \mathrm{Cu}$ and $\mathrm{Pb}$ were higher in soils than in sediments. Roots are the most efficient hyperaccumulating organs, giving higher $\mathrm{BCF}$ values. The uptake of heavy metals by the studied species followed the order: $\mathrm{Fe}>\mathrm{Mn}>\mathrm{Zn}>\mathrm{Cu}>\mathrm{Pb}>\mathrm{Cd}$. Uptake of metal ions by the different organs of the studied species followed the order: living roots $>$ dead leaves $>$ living leaves $>$ rhizomes. High TF values of the test species confirm the high capability of their roots to accumulate heavy metals and their translocation to the shoots. Therefore, rhizofiltration was found to be the best mechanism to explain Phragmites australis and Cyperus alopecuroides heavy metal acquisition capability.

Acknowledgement: The author is thankful for Dr. G.M. Fahmy, Prof. of Plant Ecology and Head of Plant and Microbiology Department, Faculty of Science, Cairo University for his valuable guidance and encouragement.

\section{References}

Alloway, B.J. and Jackson, A.P. (1991) The behavior of heavy metals in sewage-sludge amended soil, Sci. Total Environ., 100, 151-176.

Al-Sodany, Y.M., El-Sheikh, M. A. and Shaltout, K. H. (2013) Elemente accumulation and nutritive value of Phragmites australis (Cav.) Trin. Ex Steudel in Lake Burullus: A Ramsar site, Egypt, Catrina, 8(1), 55-68.

Anita, S., Rajesh, K.S., Madhoolika, A. and Fiona, M.M. (2010) Risk assessment of heavy metal toxicity through contaminated vegetables from waste water irrigated area of Varanasi, India, Tropical Ecology, 51 (2S), 375-387.

APHA (American Public Health Association) (2005) "American Water Works Association" Standard methods for the examination of water and wastewater. New York.

Baker, A.J.M. and Brooks, R.R. (1989) Terrestial higher plants which hyperaccumulate metallic elements. A review of their distribution, ecology and phytochemistry, Biorecovery, 1, 81-126.

Bolous, L. (2005) “Flora of Egypt”, Vol. 4. Al-Hadara Publishing, Cairo, Egypt.

Changcun, L., Tingcheng,Z., Li, L. and Dell, W. (2010) Influence of major nutrient elements on $\mathrm{Pb}$ accumulation of two crops from a $\mathrm{Pb}$-contaminated soil, J. Hazard. Mater, 174,202-208.

Bolous, L. and El-Hadidi, N. (1989) "The Weed Flora of Egypt". The American University In Cairo Press, Cairo, Egypt. 
Cortez, P.C.C. (2005) Assessment and phytoremediation of heavy metals in the Panlasian Creek, an unpublished High School thesis, University Science High School, Central Luzon State University, Science Cityof Mofioz, Nueva Ecija. Philippines.

Crowley, D.E., Wang, Y.C., Reid, C.P.P. and Szansiszlo, P.J. (1991) Mechanism of ion acquisition from siderophores by microorganisms and plants, Plant and Soil, 130, 179198.

Dabkowska - Naskret, H. (2003) The role of organic matter in association of zinc in selected arable soils from Kujawy Region, Org. Geochem, 34,645-649.

El-Kady, H. (2002) Seasonal variation in phytomass and nutrient status of Phragmites australis along the watercourses in the Middle Delta region, Täckholmia, 20 (2), 123 138.

Ezzat, M. N., Shehab, H., Hassan, A. A., El Sharkawy, M., El Diasty, A., El Assiouty, I., El-Gohary, F. and Tczap, A. (2002) "Survey of Nile System Pollution Sources: Report”, No, 64, APRP Water Policy Program.

Farrag, H. F.,Al-Sodany, Y. M. and Otiby,F. G. (2013) Phytoremediation and accumulation characteristics by some plants in Wadi Alargy- Wetland, Taif-KSA, App. Sci. J., 28(5), 644-653.

Gonzaga, M.I.S., Santos, J.A.G. and Ma, L.Q. (2006) Arsenic phytoextraction and hyperaccumulation by fern species, Scientia Agricola (Piracicaba, Braz.),63(1), 90101.

Hegazy, A.K., Abdel-Ghani, N.T. and El- Chaghaby, G.A. (2011) Phytoremediation of industrial wastewater potentiality by Typha domingensis, International Journal of Environment, Science and Technology, 8(3), 639-648.

Henry, J.R. (2000) In: "An Overview of Phytoremediation of Lead and Mercury", NNEMS Report, Washington, D.C.: pp, 533.

Hseu, Z.Y. (2004) Evaluating heavy metal contents in nine composts using four digestion methods. Biores. Technol., 95, 53-59.

Jensen, A. and Rasmunssen, F. (1992) Environmental contamination in Europe. Review of Environmental Contamination and Toxicology, 125, 101-181.

Kabata-Pendias, A. and Pendias, H. (1999) "Biogeochemistry of Trace Elements", Warsaw, PWN.

Kumar, N., Dushenkov, V., Motto, H. and Raskin, I. (1995) Phytoextraction: The use of plants to remove heavy metals from soils, Environ. Sci. Technol, 29(5),1232-1238.

Lasat, M.M. (2000) Phytoextraction of metals from contaminated soil: A review of plant/soil/metal interaction and assessment of pertinent agronomic issues, J. Hazard. Subst. Res., 2(5), 1-25.

Egypt. J. Bot., 55, No. 1 (2015) 
Levy, D.B., Redente, E.F. and Uphoff, G.D. (1999) Evolution of the phytotoxicity of $\mathrm{PbZn}$ tailings to big bluestem (Andropogon gerardii Vitman) and switchgrass (Panicum virgatum L.), Soil Sci., 164(6), 363375.

Liao, S.W. and Chang, W.L. (2004) Heavy metal phytoremediation by Water Hyacinth at constructed wetlands in Taiwan, J.Aquat. Plant Manage, 42, 60-68.

Lone, M.M.I. He, Z.L., Stoffello, P.J. andYang, X.E. (2008) Phytoremediation of heavy metal polluted soils and water: Progress and perspectives, J. Zhejiang Univ. Sci. B., 9(3), 210-220.

Liu, W.X., Shen,L.F., Lui, J.W., Wang, Y.W. and LI, S.R. (2007) Uptake of toxic heavy metals by rice (Oryza sativa L.) cultivated in the agricultural soils near Zingzhou City, People's Republic of China. Bull. Environ. Contamin. and Toxicology, 79, 209-213.

Mashaly, I.A., El-Shahaby, O.A. and El-Amir, Y.A. (2010) Floristic feature of the canal bank habitats, Egypt. J. Environ. Sc.

Mench, M.J., Didier, V.L., Loffler, M., Gomez, A. and Masson, P. (1994) A mimicked in situ remediation study of metal contaminated soils with emphasis on cadmium and lead, J. Environ. Qual., 23, 58-63.

Mercedes, L., Paul, K., Chris, H., Geoff, M., Gavin, F. and Charles, E. (1998) "Review of environmental performance indicators for toxic contaminants in the environment air, water and land", Technical Paper 37. Ministry for the Environment.

Mojiri, A. (2012) Phytoremediation of heavy metals from municipal wastewater by Typha domingensis, African Journal of Microbiology Research, 6(3), 643-647.

Paz-Alberto, A.M. and Sigua, G.C. (2013) Phytoremediation: A green technology to remove environmental pollutants, Amer. J. Climate Change, 2, 71-86.

Pollard, J.A. and Baker, A.J. (1997) Deterrence of herbivory by zinc hyperaccumulation in Thlaspi caerulescens, New Phytologist, 135(4), 655-658.

Schnoor, J.L., Licht, L.A., McCutcheon, S.C., Wolfe, N. and Carreira, L.H. (1995) Phytoremediation of organic and nutrient contaminant, Environ. Sci. Technol., 29, 318-323.

Shaltout, K.H., Galal, T.M. and El-Komi, T.M. (2009) Evaluation of the nutrient status of some hydrophytes in water courses of Nile Delta, Egypt, J. Bot., 1:11.

Shaltout, K.H., Galal, T.M. and El-Komi, T.M. (2013) Nutrients and heavy metals accumulation in the aboveground biomass of two perennial grasses along the water courses of Nile Delta, Egypt, $3^{\text {rd }}$ International con. Egypt. J. Bot., 17-18, 201-218.

Singh, D., Gupta, R. and Tiwari, A. (2011) Phytoremediation of lead from wastewater using aquatic plants, Int.J. Biomed. Res., 7, 411-421. 
Sukumaran, D. (2013) Phytoremediation of heavy metals from industrial effluent using constructed wetland technology, Applied Ecology and Environmental Sciences, 1(5), 92-97.

Sutapa, B. and Bhattacharyya, A.K. (2008) Heavy metal accumulation in wheat plant grown in soil amended with industrial sludge. Chemosphere, 70 (7), 12641272.

Tu, C. and Ma, L.Q. (2002) Effect of arsenic concentrations and forms on arsenic uptake by hyperaccumula, 641-647, tor Ladder Brake fern. J. Environ. Qual., 31(2).

US EPA (2001) “A citizen's Guide to Phytoremediation”, EPA publication, 542-F-98011.

Wang, Q., Cui, Y. and Dong, Y. (2002) Phytoremediation of polluted waters: potentials and prospects of wetland plants, Acta Biotechnol,. 22 (1-2), 199-208.

Xia, H. and Ma, X. (2005) Phytoremediation of ethion by water hyacinth (Echhichornia crassipes) from water. "Bioresour Technology". College of Food Sciences, Biotechnology and Environmental Engineering, Zhiejang Ghongshang University, Hangzou..

Xiong, Y.H., Yang, X.E., Ye, Z.Q. and He, Z.L. (2004) Characteristics of cadmium uptake and accumulation by two contrasting ecotypes of Sedum alfredii Hance, J.Environ.Sci. Health Part A. 39(11-12), 2925-2940.

Zayed, A., Gowthaman, S. and Terry, N. (1998) Phytoremediation of trace elements by wetland plants: 1. Duckweed, J.Environ.Qual, 27(3), 715-721.

Zeng, H. (2008) Advance in study on effects of traffic and transportation on soil and plants at both sides of road, J. Metreol.Environ., 24, 52-55.

(Received 16/9/2014; accepted 13/1/2015) 


\title{
اقتناء المعادن الثقيلة من ماء الصرف والرسوبيات والتربة باستخدام نوعين من النباتات البرمائية.
}

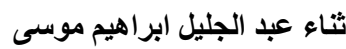 \\ قسم علم النبات والميكروبيولوجي ـ كلية العلوم- جامعة القاهرة- الجيزة ـ مصر.
}

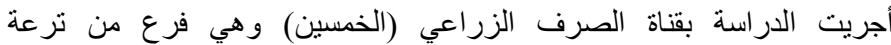

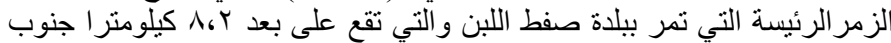

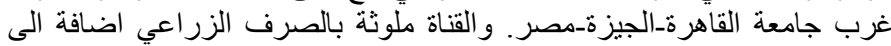

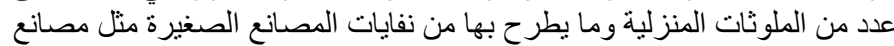

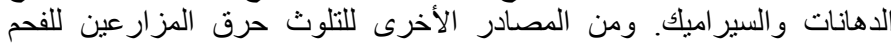

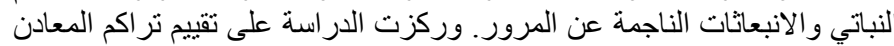

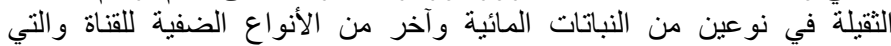

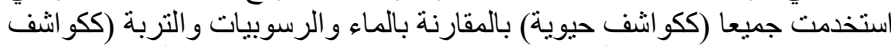

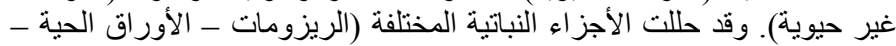

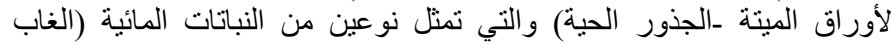

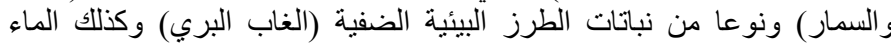

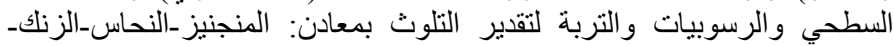

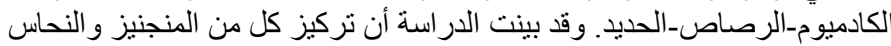
والرصاص أعلى في التربة منه في الرسوبيات. وكانت الترانت الجذور أكثر الأعضاء

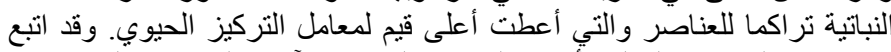

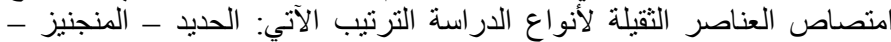

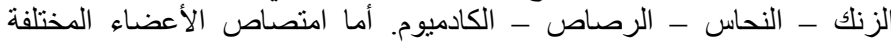

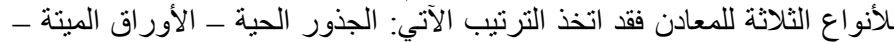



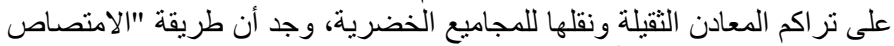
بالجذور" هي الطريقة الأفضل لتفسير قدرة كل من الغاب والسمار على على المعالجة

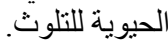

